\title{
Hvem sagde masser? Om kollektivitet og subjektivitet $i$ individets tidsalder
}

af KASPER PORSGAARD \& BRIAN BENJAMIN HANSEN

SLAGMARK \# 7 I

SIDER: $237-242$

Præcist hvem, der bør holdes ansvarlig for nedvurderingen af kollektivitet i den europæiske kulturs kanon, er et godt spørgsmål, som flere historikere egentlig burde gå op i. Er det for eksempel renæssancen eller romantikken, er det Mirandola, Shakespeare, Kant eller Goethe? Eller er denne tankegangs dominans snarere understøttet af politiske landvindinger fra kontraktteoriens konception til menneskerettighedernes indstiftelse? Hvorom alting er, lever vi i dag i en tid og en kultur, der regner individet for sit vigtigste princip både normativt og deskriptivt. Det er individets velfærd og rettigheder, ethvert moralsk system ultimativt må sigte mod, ligesom det er med udgangspunkt $i$ individets personlige kapaciteter, kompetencer, interesser og erkendeevner, at mennesket beskrives som social aktør. End ikke systemteorien og socialkonstruktivismen undslipper denne præmis, ligesom fortællinger om moderne internetkultur til stadighed dyrker individet som det, der spejles i skærmen: "Sociale medier" handler netop om individer, der næres ved den sociale kontakt og ophober social kapital. Individet er fortsat socialitetens atom. I forlængelse heraf konciperes diskussionen af sociale grupperinger (og samfund i det hele taget) typisk ud fra ideen om gruppen som en sum 
af enkeltindivider. Den vigtige samfundsproblematik bliver som følge heraf, hvordan individet kan og skal træde ind i denne gruppedannelse, hvordan individet kan acceptere at afgive autonomi heri, samt hvilken samlet handlekraft der opstår, når individer afgiver stemmer til valgene, kommunikerer, interagerer, forener sig osv. Det store skræmmebillede er i denne sammenhæng stadigvæk massen.

Massen - den uregerlige, dyriske, letpåvirkelige, potentielt ondskabsfulde masse, der opfører sig som en løbsk hjord af bisoner, eller måske ligefrem opløses i panik som hønsene i en hønsegård, når ræven er på spil. Måske var det faktisk på oplysningsfilosofiens højdepunkt, med Hegel, at massen på afgørende vis stigmatiseredes og blev sindbilledet på det ustyrlige og uregerlige. Massen er for Hegel "der Pöbel". Masse er lig med følelser og instinkt frem for selvstændig refleksion og fornuftig overvejelse, og det er en tankegang, der fortsat florerer i den kulturelle og politiske offentlighed. I firserne og halvfemserne blev danske skolebørn ikke bare bombarderet med kampagner om rygningens og narkoens farer, eller om vigtigheden af at køre med cykelhjelm. Mange af os har også været tvangsindlagt til filmen Die Welle, der beskriver et socialt eksperiment, hvor en skolelærer forsøger at indoktrinere sine elever for at vise, at nazismens forbrydelser let kan genskabes, så snart man begynder at prædike kammeratskab og sammenhold mod en ydre fjende. Skønt budskabet i Die Welle er velment, og skønt ingen selvfølgelig ønsker nazitiden tilbage, er der alligevel noget symptomatisk over filmen. Det er som om, at intet kollektivt engagement er muligt, uden at det ender i fordærv. Det er ikke så meget nazismen, der er under beskydning i filmen, det er selve kollektiviteten, massebevægelsen: Filmen angriber netop "bølgen", der skyller ind over og opsuger de sagesløse individer, som selve grundlaget for alle de ondskabsfuldheder, der udspiller sig. Og herfra er der ikke langt til at sige, at enhver entusiastisk folkemængde i sig rummer et destruktivt potentiale, der ultimativt peger mod Dachau eller Gulag. Der findes med andre ord kun gode individer (og på bunden er ethvert individ godt og behøver blot anerkendelse for at blomstre), samt (mere eller mindre) dårlige masser og massestrukturer. Måske er det vi mister, når massen bruges som skræmmebillede, dog netop muligheden for ægte politik, i en betydning af ordet, der rækker ud over den institutionaliserede stemmeafgivelse og administrerede politik, som vi 
kender det i dagens vestlige samfund? Måske skal politik, forstået som mere radikale forandringer og bevægelser, netop tænkes gennem begrebet 'masse', sådan som Mladen Dolar har antydet i artiklen "Freud og det politiske". Artiklen er i første omgang en kommentar til Sigmund Freuds ret negative forhold til politik og til massen. Men som Dolar udtrykker det, kan man med massebegrebet måske netop sige noget om "det politiske som en forvridning af de eksisterende sociale enheder, som en omlægning af det grundlag, der holder de eksisterende relationer sammen". Massen er altså det, der potentielt opløser herskende sociale bånd og hierarkier. Som sådan kan den netop fungere frigørende i situationer, hvor vi ideologisk er kørt fast, hvor summen af individer, meninger og interesser er talt op, og hvor alle råd og nævn synes endegyldigt etableret. Det er dog klart, at masser både har bagsider og slagsider, og som Dolar videre påpeger, er der "ingen tvivl om, at man ikke bør bekæmpe Freuds barske vision med en rosenrød vision, med det romantiske billede af de revolutionære masser, der stræber efter frihed, efter at bryde deres lænker og indsætte et direkte demokrati, når de først har kastet dominansens åg af sig." Det er bestemt vigtigt at være opmærksom på de farer, der følger med alle massebevægelser. Men disse farer er kun den ene side af den farefulde men også eventyrlige færd, som politik er. Måske kunne man endda sige, at det 20. århundredes totalitære massebevægelser, fascistiske, nazistiske og kommunistiske, delvist var resultatet af en filosofisk forsømmelse: Når massen ikke må tænkes, eller når man ikke må tænke med den, synes den kun at vise sig i sine mest brutale og perverterede former. Sagen er overhovedet at begynde at forstå, hvad masser er i stand til.

Det forekommer imidlertid i dag næsten umuligt at forestille sig "tænkende masser". Da masser per definition er flygtige, irrationelle og uberegnelige, kan de ikke tilskrives tænkning og refleksion. Det er netop her, Badiou med sit begreb om det kollektive subjekt, udviklet allerede i Théorie du sujet (1982), og videreført i L'Être et l'Événement (1988) og Logiques des mondes (2005), står frem. Det er i kombinationen af det kollektive med det subjektive, at hans position finder en styrke, og han indskriver sig hermed i den ret beskedne række af filosoffer, der i meget afgørende grad er inspireret af strukturalismen og den opløsning af det individuelle perspektiv, der uvægerligt fulgte, men samtidig ønsker at bevare eller forsvare subjektet. For Badiou er det at blive et 
subjekt at forstå som en begivenhed, der altid er minimalt kollektiv. Subjekter opstår for Badiou rundt om begivenheder, der har kollektiv værdi, og som kræver kollektiv udforskning, nysgerrighed, engagement og tænkning. Det være sig en politisk manifestation, et kunstnerisk nybrud eller en videnskabelig opfindelse. Et "politisk subjekt" er således ikke et individ, der interesserer sig ekstra meget for politik, men et agerende og tænkende kollektiv, som med udgangspunkt $\mathrm{i}$ konkrete situationer undersøger nye former for sameksistens. Det er for Badiou netop ikke et spørgsmål om sociologisk at forklare, hvordan politik, kunst og videnskab udvikler sig i fællesskaber, der er dannet gennem diverse alliancer og kompromisser, men derimod et spørgsmål om at beskrive og forsvare bestemte former for disciplineret sandhedssøgende kollektivitet, der først for alvor giver de deltagende individer adgang til meningsfuld subjektivitet.

Badiou giver således den kollektive handlen sin fulde værdi tilbage. Ikke i form af en mystisk forening eller en diffus bevægelse (hvilket igen blot ville påkalde associationer til drifter, ekstase, anarki, lige dele Roskildefestival og pinsekirkelig tungetale). Det drejer sig simpelthen om, at en hidtil ikkeeksisterende gruppe melder sin eksistens i verden. Hvis en 'verden' består af den inventarliste og det koordinatsæt, som en given geograf kunne vælge at skrive, så består den politiske begivenhed i, at de, der konkret lever i denne verden, men uden symbolsk repræsentation, pludselig melder sig i den, og det i form af en erkloring eller en proklamation. Man kan illustrere det med udtrykket "at komme ind i kampen," forudsat at man forfølger dette billedlige udtryk til sit mest overraskende scenarie. At komme ind $\mathrm{i}$ kampen på Badiousk manér svarer ikke til, at en fodboldspiller, der har siddet på bænken hele kampen pludselig bliver beordret på banen af sin træner. Det består heller ikke i den mere rebelske variant, hvor man kunne forestille sig en fodboldspiller pludseligt overrule sin træner og selv løbe ind på banen (sådan som Günther Netzer engang legendarisk gjorde det for Borussia Mönchengladbach - og i øvrigt scorede! $!^{1}$. Nej, man må snarere forestille sig, at fodboldbanen pludselig invaderes af et helt hold af synkronsvømmere, der blander sig ind mellem spillere og dommere, forrykker al koordination og formål med spillet og klart erklærer: "Vi er her nu. Spillet er et andet." Erklæringerne er det, som gør massen tænkende. 
Ifølge Badiou er enhver situation specifik og kræver sine egne erklæringer, der imod de herskende og statsligt understøttede strukturer skaber nyt rum for praktiseret politik. Det er dertil erklæringernes universalistiske sigte, der afgør deres politiske potentiale, samt lægger linjen for den proces eller sekvens, som indfrielsen af erklæringerne fordrer. Der er ikke tale om hensigtserklæringer, som ville kunne indfries, hvis disse erklæringer kunne godtages af vælgerne én for én. Der er tale om, som Badiou også udtrykker det, at erklæringerne oprinder i en generel vilje, der praktiseres her og nu, og som kun eksisterer som en fælles eller kollektiv vilje. Sådanne erklæringer kan være i konkurrence med både herskende meninger og strukturer, men peger netop hermed på andre dimensioner af det politiske, nye måder vi kunne indrette samfundet på. Det mest iøjnefaldende ved de massebevægelser, vi har set, siden det arabiske forår blev skudt i gang, har måske netop været den strøm af erklæringer, forsøg på erklæringer, udveksling af erklæringer, der er blevet produceret i Egypten, i Zucotti Park i New York, hos Los Indignados i Spanien og mange andre steder. Fra erklæringerne under det arabiske forår, som hverken tog side for det herskende styre eller en vestlig model, men pegede på et nyt Egypten, der gør op med korruption og ulighed, og til Occupy Wall Streets mere søgende krav og erklæringer. Som en slags metaerklæring fremsatte Los Indignados i 2012 det fine: Hvis I ikke giver os lov til at drømme, giver vi jer ikke lov til at sove. Med andre ord: Hvis vi ikke får lov til at drømme, at producere erklæringer, bliver det værst for jer selv. Erklæringerne er massens primære udtryk, kunne man sige, mens først undertrykkelsen af disse erklæringer og massens muligheder for at producere dem, gør massen konfrontatorisk.

"Det taler", sagde Jacques Lacan engang om det ubevidste, selvom om det ret beset lyder underligt at sige, at det er det ubevidste, der taler, og ikke mig, forstået som min individuelle, selvbevidste personlighed. På en tilsvarende måde er det imidlertid med massen. Den taler. Massen er baseret på erklæringer, som enhver enten kan afvise eller affirmere. Med et udtryk lånt fra (den sene) Sartre, som Badiou i høj grad er inspireret af, kan man tale om, at der i tænkende masser findes en såkaldt "tredjepart". Tredjeparten er den åbne plads i massen, hvorfra massen taler. Det er ikke mig eller min sidemand, der repræsenterer massen ved at tale på dens vegne. Det er massen, der taler gennem mig, når jeg indtager tredjeparten - og om det er mig eller 
min sidemand, der konkret bruger stemmebåndet, er i denne sammenhæng underordnet. Tredjeparten er både en radikal åbenhed, idet alle kan tale fra denne position, men indeholder også en disciplin: Kunsten er netop at tale som et alle.

Rene masser, dvs. masser uden erklæringer, er uinteressante. Sådanne masser skaber ikke historien, som 68'erne ellers havde for vane at sige. Det interessante er tænkende, talende masser. Det er måske netop kombinationen af det tænkende, universalistiske moment med massens energi og tyngde, der er brug for i dag.

Kasper Porsgaard og Brian Benjamin Hansen er medlemmer af filosofkollektivet Center for Vild Analyse.

NOTE

1 https://www.youtube.com/watch?v=yPVpJlYWTlg 